\title{
CSR and leadership approaches and practices: a comparative inquiry of owners and professional executives
}

\begin{abstract}
This study generates comparative insights into CSR approaches of owners and non-kin professional executives in an emerging country context, Turkey. Drawing on 61 interviews, we found that ownership status of the executive is crucial in shaping their CSR perceptions and practices. Owner-executives are empowered in pursuing CSR approaches based on their personal preferences and values; they have mostly societal aims. Professionals display tendency for company-related CSR practice; they exhibit greater knowledge of CSR, and their CSR initiatives are the results of strategic choices to enhance their power within the corporation. Our paper contributes to the debate on the drivers for CSR by accounting for both societal and individual influences on the CSR agency of these two key groups of executives. First, we develop a typology of CSR approaches of owners and professionals. Second, we provide insights from an emerging country context. Third, we present empirically grounded practice implications for CSR.
\end{abstract}

Keywords: CSR, owner-executive, professional executive, Turkey, qualitative

\section{INTRODUCTION}

One of the most influential family business groups, Sabanci group, organizes Akbank Jazz Days as part of their corporate social responsibility (CSR) activities. Given the traditional cultural outlook of Turkey, only $3.8 \%$ of the Turkish population listens to jazz music (Hurriyet, 2011). Akbank Jazz Days is an illustrative example of arguably controversial nature of CSR decisions. The puzzle of how and as a result of what influences CSR decisions intrigued us in exploring the topic and we focused on one particular aspect of the problem, 
which is the interplay between the owner vs. non-owner status of the company executive and their CSR perceptions/ practices.

We present a comparative investigation of CSR perceptions and practices of owners and non-kin professional executives, reporting on a qualitative study undertaken in Turkey. Public debates on socially responsible corporate practices have become commonplace in the aftermath of the global financial meltdown, and yet CSR frameworks, which are used to elaborate the expectations from corporations, are characterized by a wide range of conceptual definitions. Thus, it is crucial to start with conceptual clarity. CSR is ideologically framed; in this paper we conceptualize CSR as one form of business-society interactions that reflects particular ideological framing (Djelic and Etchanchu, 2017). How the nature, extent and impact of CSR has changed through time and space and co-evolved with shifts in dominant ideologies is important. Transformation of the intentions of leaders that motivate the exercise of CSR is significant. In-depth studies that examine motivations and practices of different groups of business elites are required to shed further light into our understanding of CSR.

The key questions we set out to answer in this paper are: How do owners (family member executives) and non-kin professional executives in Turkey perceive and practice CSR? In answering this question, we pay particular attention to the nuanced convergences and divergences in CSR approaches and practices The Turkish business context is dominated by family business holdings, which grant a privileged position to owning family. Usually one or two families possess the majority of the shares and they are also present in the control of the company. However, as companies expand and are passed down through generations of owners, a community of professional executives also emerges. Therefore, it is important to investigate and compare the CSR perceptions and practices of owners and professional executives in order to understand CSR in the context of an emerging economy. Through a comparative approach, we are able to shed light on the factors that shape CSR practice. A 
comparison of these two groups of upper echelons, who are distinct in terms of their legitimacy claims and their access to executive power and resources, provides insights into key drivers for adoption of various CSR practices.

In delineating the ideological and power-laden nature of CSR practice, our paper compares the CSR approaches and practices of owners and non-kin professional executives, who are arguably the two main groups of business leaders. A growing body of literature examines approaches and practices of owners (owner-executives) in the area of social responsibility, and highlights the significance of owners in developing and implementing CSR, particularly in the context of SMEs (Baumann-Pauly, Wickert, Spence and Scherer, 2013; Besser, 2012; Del Baldo, 2010; Fassin, Van Rossem and Buelens, 2010; Fassin, Werner, Van Rossem, Signori and Garriga et al., 2015; Jenkins, 2006; Lahdesmaki, 2012; Murillo and Lozano, 2006; Perrini, 2006; Russo and Tencati, 2008). However, there is a dearth of comparative studies examining perceptual differences between owners and professional executives. One particular study by Tafel-Viia and Alas (2009) analyzed such differences as sources of conflict in the context of Estonian SMEs. The authors argue that the focus of emphasis differs between owners and professional executives, mainly due to their different roles in an organization. Owners tend to develop and use CSR as a strategic tool in order to relate to certain interest groups and stakeholders, such as the state, politicians, media and public opinion, whereas professional managers focus on other stakeholder groups, such as suppliers, customers and employees. Nevertheless, the research on owners often focuses on the SME context. Our study makes a unique contribution by comparing leadership perceptions and practices of owners and non-kin professional executives in relation to CSR practice in 61 of the largest Turkish companies.

As noted, CSR needs to be understood on a particular and contextual form of business-society interactions that reflects and reveals certain institutional and cultural 
conditions, particular relations of power and a given ideological grounding (Djelic and Etchanchu, 2017, p. 644). Turkey constitutes an intriguing context to answer our research question for a number of reasons. Unsurprisingly, CSR is less studied in non-Western contexts, a gap which is even more acute when it comes to CSR perceptions and practices of owner- and professional executives in large companies. The very concept of CSR plays, in actual circumstances of Turkey, a well-placed tool for measuring the nature of perceptual mixtures that business-people develop to find a tactical path (De Certeau, 2002), which could serve them as actors to effectively exist in the highly competitive circumstances of the global market. Furthermore, Turkey has neither been colonized as most developing countries nor it experienced a Western-type of modernization. Yet it is characterized with an astonishing capability to adopt modern institutions through original synthesis, mostly channeling traditional values in modern forms. For example, as our study uncovers, the unique historical experience of Turkey in modernization is observed in the polysemic understanding of corporate social responsibility by owners, but mostly on philanthropic-basis. Consequently, the analysis of the perception and practices of CSR in Turkey has the potential for revealing, not only the existing variety of approaches to the concept, but especially the internal logic of a complex social change.

Situated at the intersection of Europe and Middle East and connected to the ancient Silk Road across Central Asia through Turkic culture after the fall of Soviet Union (Morgan, Hirsh and Quack, 2015), Turkey constitutes an interesting setting to study CSR practices. This is a melting pot where west and east as well as modern and traditional meet. In fact, while the policy shifts towards liberalization in 1980s relocated Turkey more into the mainstream of the world economy, the rise of Islamic parties in 2000s has created a business elite less unitary and more divided by the issues of religion, secularism and free markets (Morgan, Hirsh and 
Quack, 2015). This intermingling of modern and traditional as well as frequent macro changes may have different repercussions on CSR understanding of the owners versus professionals in large business groups in Turkey. While the owners inherit the highest position in the power scale, the recent fast economic growth contributed to the size and status of the manager category in Turkish business system (Yamak and Ertuna, 2017). The latter with degrees in management and engineering from western-tradition higher education institutions are more exposed to western business practices (Yamak, 1998). In a longitudinal study, Yamak (2007) found that the concept of CSR was largely imported from the USA in Turkish academic circles, with no investigation of the previous CSR practices and concepts in this particular context. This strand of CSR literature misses previous sector or society level solidarity institutions and zakat mechanism. Therefore, the Turkish management literature on CSR appeared to be detached from the country specific context and history up to the early 2000s. Recent studies attempt to fill this gap and indicate that philanthropy originating from culture and traditions coexists with imported notions of CSR (Alakavuklar et al., 2009; Ertuna and Tükel, 2009; Küskü and Bay, 2012) contrary to the views of Ararat (2008), who maintains that societal influence is not strong on corporate behavior in Turkey, and that multinational companies with their control over their supply chain are among the major forces promoting, for example, environmentally-friendly technologies. This co-existence of modern and traditional may influence the way owner and professional executives understand and implement CSR. There are limited findings related to managerial behavior. Ascigil (2003) investigated managers' understanding of CSR, and found that CSR is mostly perceived as a public relations issue. However, in her 2008 study conducted amongst professionals in Turkey, Türker observed that CSR activities positively contribute to commitment, and that they mostly reflect the personal interests, values and preferences of strategic leaders in Turkish companies whereby the majority of the shares belong to one or two families (Bulut 
and Yumrukaya, 2009). CSR in Turkey appears to be of a philanthropic nature which, according to Robertson (2009), is consistent with the existing family ownership structure. At this juncture, it is essential to underline that particularly in culturally hybrid and dynamic contexts such as Turkey, CSR aspirations of owner- and professional executives may differ significantly and they may be prone to specific CSR approaches, knowingly or unknowingly as a result of the strong interplay between ownership status and executive agency. By focusing on this previously overlooked aspect of CSR practice, our study differentiates the owners from professional non-kin executives, and presents novel insights, which will be particularly relevant for similar societal contexts where traditional and modern mingles.

To summarize, the contribution of our study is threefold. First, we offer a typology of owners and non-kin professional executives that highlights characteristic differences in approaches and practices/actions pertaining to CSR. This typology is built around a key finding of the study that demonstrates a significant difference between owners and non-kin professional executives in their CSR perceptions and practices. We contribute to the literature by addressing a gap in the comparative understanding of CSR from an ownership and leadership perspective. Our paper demonstrated that the position of the executive vis-à-vis economic capital (i.e. ownership) is an important indicator of their notions of CSR. It is possible to locate both groups' approach to CSR along a continuum, ranging from a lack of any notion of CSR to highly institutionalized practices referring to a particular macro-view of society. Thus, we contribute to the body of literature on the main drivers for, obstacles against and contradictions in CSR practice by introducing a typology that describes the executive agency for CSR as an outcome of the interplay between societal and individual factors, between material circumstances and personally held values and beliefs pertaining to CSR.

Our second contribution is that we offer original empirical insights on CSR in the context of an emerging country, Turkey. As explained above Turkey presents a relevant 
context for our research. The majority of research on CSR has focused on understandings and practices in developed economies. Our study addresses this gap through an investigation of the topic in Turkey, which offers an interesting context within a dynamic socio-economic, political and cultural environment. Our findings reveal dual nature of CSR in Turkey, characterized by diffusionist tendencies for professional executives and traditional tendencies for owners.

Our third contribution pertains to the practical implications of our study. The investigation of the perception of different groups of business leaders (e.g. owners and professional executives) concerning CSR potentially have significant implications for CSR practice in terms of how to improve CSR understanding and practices in emerging country contexts. CSR remains to be an imported concept in most of the emerging country contexts; and hence we observe its artificial applications with taken-for-granted assumptions. We suggest that CSR responsiveness of business elites are embodied in their questioning and sense-making processes of their own assumptions, ideologies, motives as well as power. Featuring corporate executives as 'moral agents', which highlights the role of managerial discretion as a driver of CSR (Wood, 1991; Carroll and Bucholtz, 2006), our findings advocate that a better understanding of the link between CSR perceptions and approaches of the executives underpins the development of a responsible leadership approach towards CSR.

The remainder of this article is structured as follows: Firstly, we discuss the conceptual underpinnings of our study. In this section, we begin by discussing our conceptualization of CSR with a focus on agency of CSR leaders. Next, we outline the research methodology. The research findings are then presented, followed by a discussion of key findings, and, finally, our conclusions. 


\section{CONCEPTUALIZING CSR WITH A FOCUS ON AGENTIC CAPACITY}

\section{OF LEADERS}

CSR has been conceptualized and debated from various perspectives. One of the most frequently cited studies is Carroll's work (1979, 1981, 1991, 1999), which defined CSR as "the social responsibility of business, which encompasses the economic, legal, ethical and discretionary expectations that society has of organizations at a given point in time" (Carroll, 1979, p.500). Expanding on Carroll's four pillars of CSR, Wood (1991) proposed a multilevel conceptualization and focused on CSR principles of social legitimacy (institutional level), public responsibility (organizational level) and managerial discretion (individual level) in defining the concept. Managerial discretion and practice (De Cremer et al., 2011; Carrington, Zwick and Neville, 2018; Legrand, Al-Ariss and Bozionelos, 2018) is fundamentally important in defining CSR, particularly for the purpose of this study.

In this paper, CSR is defined as an organization's commitment and active response to issues beyond the narrow economic, operational, legal and ethical requirements of the business (Carroll, 1979, 1991, 1999), as a particular form of business-society interaction embedded in certain ideological and cultural conditions with associated power relations (Djelic and Etchanchu, 2017). It is about using the intrinsic capacity of the firm to improve the condition of its society through collaborative solutions to problems that arise due to market failures (Kemper and Martin, 2010). Aligned with this understanding, CSR initiatives entail a business organization contributing a combination of its resources for a social impact outside the normal scope of the corporation (Isaksson, Kiessling and Harvey, 2014). This expanded notion of CSR differs from a conventional understanding of it in terms of philanthropy; from a normative perspective that emphasizes compliance with standards relating to corporate behavior (Deakin and Whittaker, 2007; Epstein, 1987), and from the 
market orientation perspective that insists on the relationship between CSR and the firm's increasing competitive advantage (Brik, Rettab, and Mellahi, 2011).

CSR dynamics can be better understood by taking into account the socio-economic, political and institutional context. Political and societal expectations of business responsibility are important considerations. Scherer and Palazzo (2007) suggest a 'political CSR' perspective that has five interrelated dimensions: governance model, role of law (Elsayed, 2010), scope of corporate responsibility, source of corporate legitimacy, and the role of democracy. Role of governments in driving CSR particularly in emerging economies is illustrative of authoritarian capitalism, in the words of Hofman, Moon and Wu (2017). This debate is also related to a wider understanding of the people who constitute a corporation, including owner, professional executives and a whole range of stakeholder groups (Sison, 2009) and their expectations vis a vis business responsibility. The role of executives in driving CSR (see Cabeza-Garcia, Fernandez-Gago and Nieto, 2017) in the form of tuning their organizations into social concerns and engaging in value-laden organizational decision making processes (Swanson, 2013) to respond to multiple stakeholders is of fundamental importance.

Limited research has explored the implications of ownership, and shareholder rights and power for CSR (Angus-Leppan, Metcalf, and Benn, 2010; Arora and Dharwadkar, 2011; Mellahi, Frynas, Sun, Siegel, 2016; Waldman and Siegel, 2008). The propensity of corporations to engage in CSR is found to be associated with individual characteristics of CEO such as ownership rights, intellectual stimulation, values and leadership styles (Jiang, Zalan, Tse and Shen, 2018; Legrand et al., 2018; Groves and LaRocca, 2011; Waldman et al., 2006). For example, Du et al. (2013) investigate how leadership styles affect firm's CSR practices and organizational outcomes. They argue that greater transformational leadership brings about more engagement with CSR. In another study, Vlachos et al. (2013) suggest that 
a manager's charismatic leadership influences employees' interpretations of the motives underlying their organizations' engagement in CSR. Jiraporn and Chintrakarn’s (2013) study on the effect of CEO power on CSR illustrate the significant impact of managerial power and agency on corporate CSR practices. They suggest that as the CEOs become more powerful, they increase investments in CSR, as they recognize wider benefits of CSR to themselves and to their organizations.

Moving Jiraporn and Chintrakarn’s (2013) argument forward we circumscribe CSR practice as outcomes of agency power relationship, rather than improvised or structurally determined duties. Following mainly the conceptualization of Giddens (1989) on agency, we assert that CSR-related agency of executives is tightly dependent on the ability to mobilize resources that are controlled by and constitutive of a high-grade executive position. Giddens (1989), in an effort to save the concept agent from both functionalist and hermeneutic notions of overly determined or overly autonomous acting subject, introduces a dialectical matrix in which reflexive monitoring, rationalization and motivation of action, are three dimensions of agency. Such a distinction means, in Giddens' terms (1989), a constant interpenetration between unconscious (unintended) and conscious (intended) components of a social act. By inserting an intermediary level between unconsciousness and consciousness, Giddens (1989) underlines that between perceptively hidden aspects of an act and the intellectually pertinent state of it; there is the practical motives. In other words, Giddens (1989) attributes a particular importance to the practical knowledge issuing from an articulation of reflexive framing and unconscious motivations that construct an act. In this framework, agency is not considered solely a pure product of full or reflexive consciousness but is rather an encounter of the unconscious motives and rationally-oriented action, a knowledge of doing (Giddens, 1989). Our understanding of CSR activities and actions are based on such a conception of practice as 
a function of confirming the agency-power relationship for owner and professional executives.

\section{METHODOLOGY}

\section{Research design and sample}

This is an exploratory qualitative study (Symon and Cassell, 2012; Myers, 2013) whereby we have sought to investigate an area that has been under-researched in the CSR domain. In this article, we report on a sub-section of findings of a broader study on Turkish business elites, which was carried out with a grant supplied by the Scientific and Technological Research Council of Turkey. This broader study included interrelated sections on CSR, corporate governance and strategy, political and business networks, entrepreneurial attributes, and gender and family dynamics amongst others. The interviews were conducted between August 2009 and February 2011. The sample of the study was drawn from top executives of the largest Turkish companies ranked by the Istanbul Chamber of Industry. Since we were keen to have a country-wide representative sample of the business elite, stratified random sampling was used. For this purpose, we have taken into consideration the regional breakdown of the 500 largest companies, and the sample included top executives from both rising and declining regions across Turkey. Approximately 45 per cent of the companies in our sample originate from Istanbul and the remaining 55 per cent from the rest of the country, reflecting the regional distribution of the largest companies in Turkey.

In defining owner-executives, we used having a kinship tie with the owner/founder of the company as the criterion. Top executives, who possess ownership stakes in the company and have kinship ties with the founder/owner family as extended family members (the 
spouse(s), children, grandchildren and siblings of the founder(s), spouses of their children, grandchildren and siblings, nephews and nieces of the founder(s) and spouses of these nephews and nieces), were regarded as owner-executives (Selekler-Goksen \& Usdiken, 2001). Professional executives were defined as top executives with no kinship links with the founder/owner family. The distributive attributes of our participants are presented in Appendix 1.

\section{Data collection and analysis procedures}

In this exploratory study, 65 open-ended narrative interviews were carried out with the key informants holding executive roles, such as the CEO, chair, or vice-chair of the board in each company. Of these, 61 interviews were deemed usable in terms of CSR questions and included in our analysis in the current article. Four interviews were excluded due to the fact that interviewees did not have time to answer the majority of the questions on business and society relations and CSR. Narrative interviews (see Alvesson and Ashcraft, 2013) allowed us to pay considerable attention to insightful accounts of participants.

The interview protocol included life stories of the participants as well as questions on the history of the company; business and society relations in terms of their interactions with the state, corporate CSR approach, strategies and practices; key drivers and motivation for CSR activities; and participants' personal views on, and perceptions of CSR among other topics covered by the larger study. The interview protocol was a broad guide, which provided us with the opportunity to start with more generic questions and to ask for further elucidation in the course of the interview. This strategy enabled us to elicit different viewpoints and deeper insights into CSR and test our own evolving understanding of the CSR context in Turkish organizations. We framed our questions drawing on the existing literature as well as initial feedback we obtained through pilot interviews with top executives of five corporations. 
Our interviews were structured along two axes (Bacharach, Bamberger and McKinney, 2000): first, informant's background, knowledge, work and family context, and second, description of individual cases as life stories along with the company stories, focusing on different aspects along with business and society interaction, CSR-related stories, for the purposes of the current study.

The interviews were undertaken in the premises of the research participants. This has given us the opportunity to take field notes in relation to the office and the company. The awards, certificates and photos in relation to their CSR activities were important sources of information. We had the triangulation of data sources by using interviews, archival data and office observation. At least two researchers were present at each interview, except in two cases. Interviews typically lasted two to three hours and were tape-recorded. In two cases where tape-recording was not permitted, detailed notes were taken during the interviews. To improve the accuracy of the responses and adhere to research ethics, interviewees were assured that their replies would be kept strictly confidential. We have concealed the names of individuals and organizations by using numbers in our research report and consequent publications.

The data obtained through interviews were also crosschecked with the archival data. An extensive documentary search has been conducted in relation to each interviewee and firm using the Internet and database/electronic resources of libraries. Field notes and archival searches contributed significantly to our understanding of the context surrounding the participant and thus to better comprehend the interview narratives. We have applied thematic analysis to analyze the interview data. The usual procedure in thematic analysis entails methodical codification of empirical material. It consists of encoding qualitative data by using explicit codes, leading to themes, which are patterns identified in the data (Boyatzis, 1998). In line with narrative thematic analysis, we have employed a data-driven approach and 
developed the codes and themes inductively. For reliability, two different researchers independently coded the data. When an agreement could not be reached among the two researchers, the theme was dropped from analysis or reconstructed until full agreement was reached between the researchers.

Our key focus in developing the codes and categories of themes related to CSR was on executive motives (linked to their legitimacy claims and access to power and resources) and key drivers for adoption of CSR approaches and practices including CSR understandings. Thematic analysis has allowed us to develop categories of themes to assess the scope of CSR understanding and practices of executives ranging from a level of no awareness or limited understanding of CSR (only in terms of economic responsibilities for instance), to a more holistic perspective of CSR embracing diverse types of stakeholders. These categories will be further illuminated when we present and discuss research findings. The interviews together with the field notes and archival data have been cut into first order and second order codes which led to aggregate themes drawing on Gioia et al.'s (2013) framework. The coding scheme that is generated through data analysis is presented in Figure 1.

\section{Insert Figure 1 about here}

Since our overall objective is to generate insights into an under-researched phenomenon through rich examples of CSR accounts by owners and professional executives, transferability (Lincoln and Guba, 1985; Patton, 2015), rather than generalizability, is aimed in this research. By generating a typology of CSR approaches of family member executives and non-kin professional executives, our aim is to demonstrate one potential way of looking into differences in motives and understanding and practices adopted by these groups of top

executives in the context of CSR. As aligned with our conceptualization of agency (Giddens, 1989), interrelated dimensions such as reflexive monitoring, rationalization and motivation of 
action are implicitly embedded in our analysis. Intra- and inter- group differences are brought to the fore of the discussion in order to delineate the categorization developed for the typology.

\section{RESEARCH FINDINGS}

The majority of the respondents - 80 per cent of the sample - were owners, consistent with the fact that family business groups and family management dominate the Turkish business system (Yamak and Ertuna, 2012; Buğra, 1994). Non-kin professional executives constituted the minority of final decision-makers, both at the single business level and business groups level, due to their relatively weak position in the Turkish business system (Yamak, Ertuna and Bolak, 2006).

We constructed a typology of CSR awareness and practices along a continuum, which encompasses varied tendencies among owners and non-kin professional executives as can be seen in Figure 2. This approach allowed us to compare the two key groups of executives as main categories, but also according to their inner varieties. Both extrapolations seem to have a crucial functionality for a better understanding of not only CSR practices, but also of the significant discrepancies between the perceptions of the very concept of CSR. Indeed, as shown below, before identifying different CSR projects and values underlying them, we have noted that a series of differences exists among top executives in terms of their conceptions of CSR. 
In presenting the findings of our research, we first present the intra-group analysis followed by the inter-group analysis of owner- and professional executives, which form the basis of our evidence-based typology.

\section{CSR perceptions and practices of owner - executives}

Owners demonstrate important intra-group differences in terms of CSR perception and practices. At one end of our spectrum in Figure 2, there are owners who are unaware of, or insensitive to the CSR concept (i.e. 'ignorant/insensitive owners') and at the other end are those with sophisticated understanding and internalized commitment to CSR (i.e. 'valuebased owners').

Ignorant/insensitive owners: This group is characterized by a lack of awareness of CSR, or with a low sensitivity to stakeholder needs and almost no reaction to the social and environmental dimensions of the business. The basic characteristic of the 'ignorant/insensitive owners' group is that they are all company founders. There is a considerable variation in company age, as they established their firms at separate times. All except one are university graduates and all are male (seven in total). Another striking issue is that, again except for one, they all have export-oriented and smaller size companies. Export orientation may decrease legitimacy creation need in local markets. For example, one of the interviewees, ignorant of the CSR concept, was totally focused on company profit and he had no awareness of corporate responsibilities towards employees, environment and other stakeholders. He had an internalized notion of exploitation of both human and natural resources as indicated in A1 in Table 1. Another participant defined company CSR activity as: “My daughter sold her artwork once to help the poor" (Male, 51, owner of a large industrial firm). Indeed, some of the owners had difficulty in understanding the concept when it was referred to as CSR and 
responded to the question on whether they have CSR activities in the company with a simple “no”. Their concept of doing business did not include any particular sensitivity or reflection on their responsibilities towards stakeholders.

\section{Insert Table 1 about here}

Pragmatist owners: Next on the continuum is the group labelled 'pragmatist owners', who understand CSR and act upon CSR matters, reflecting conformist, instrumentalist and personal preferences on a transactional basis. Hence their practices do not go beyond the transactional pursuit of unsystematic and uncoordinated CSR activities, which mainly serve company interests. There are 17 owners in this category and all are male and university graduates. Their companies do not have a common characteristic in terms of age, size or export orientation.

In this group, we identified a group of owners, who perceived CSR as a tool for easing the life of the firm through networks with local regulatory institutions. For example, one respondent defined CSR along the lines of "providing what municipality asks from us” (Male, 51, owner of a large industrial firm). The same person stressed the "need of getting along with the municipality which otherwise may make life hard for the business". He stated that he constructed a basketball ground for the municipality upon their request; similar comments were also made by several others. For this group of owners, CSR is seen from an instrumentalist approach, based on limited awareness of CSR matters and limited sensitivity to different stakeholders focusing only on those which will contribute to their business and which can even be considered as bribe in some instances (see A2-1 and A2-2 in Table 1).

Instrumentalism took different shapes and forms in terms of its extent, spanning from narrow business-driven instrumentalism, as demonstrated by A2-1, to future-oriented social 
engineering (A2-2). The words of one of the respondents display how some owners linked CSR activities to the mid-term changes in the talent pool: "We have constructed high schools related to our industry.” (Male, 59, owner of group of companies). Others had more longterm, large-scale and explicitly ideological visions linking CSR and business interests as illustrates A2-2. In these instances, CSR is used as a medium for indirectly influencing national politics. In this group, there was a rational and instrumentalist pursuit of unsystematic CSR activities, based on personal preferences and requests that are made by local authorities and some fractions of the community. This demonstrates evidence to encounter between unconscious motives and rationally oriented action in navigating through decision making and implementation in relation to CSR.

Paternalist owners: Further along the continuum are owner who are expressively aiming to contribute to the society. We label this group 'paternalist owners'. The paternalist owner has a CSR notion that is imbued with traditions and underpinned by religion in some cases. CSR activities appear as instruments of expressing the personal managerial power and will of owners. These 21 owners have different demographic characteristics and so do their companies. No pattern other than their predominantly provincial background could be observed in terms of their characteristics. We identified two sub-groups in this category: the first comprises of those paternalist owners who perceive CSR as the moral and implicitly religious duty of the 'businessman'. They perform philanthropic acts on their own, rejecting the tax advantages they may have, and are usually the smaller scale owners within our sample of large corporations (A3-1 on Table 1). The second sub-group of paternalist owners includes those who undertake philanthropic activities, which are organized at company level and carried out in a relatively systematic way by setting up foundations. As the company grows, owners tend to prefer more institutionalized and regular large-scale activities. CSR activities 
are organized through foundations of the enterprise or the family, which allow for more structured governance (A3-2 in Table 1). Forming an example to rationally oriented action, these findings also exemplify the dual nature of agency in terms of balancing between unconscious motives (e.g. religious motives and traditions) and deliberate action.

Value-based owners: Finally, the very end of the continuum is termed the 'value-based owners'. This category represents the smallest group in our sample. Four out of 49 owners fit into this category. They are all university graduates and executives of diversified group of companies. Such value-based owners display an important level of personal involvement in CSR activities along different lines. Their perception of CSR is defined by personal selfactualization, and enlightened view of and individual responsibility towards the society which comprises a sustainability notion (A4-1 and A4-2). This type of owners' CSR perception is imbued with a holistic approach to socio-economic and political issues in their surroundings, and not necessarily confined to their immediate community, and their CSR practices are therefore exemplified by activities that have an ultimate objective of affecting societal change along their ideologies, as delineated by the concept of reflexive monitoring. CSR projects and the values underpinning the companies of owners in this category tend to function on a higher register than the ordinary philanthropic activities undertaken by the economic actors. This can be construed as a form of undertaking political acts without concretely entering into the domain of the realpolitik. Value-based owners have a rounded perspective on CSR that brings about the execution of discretionary power in order to make an impact on the society. This shows the dialectical agency-power relationship as introduced in the preceding conceptual section of our paper.

In this group, CSR perception is highly value-based, and business ethics is strongly emphasized. CSR practices portray high sensitivity to stakeholders, community and the 
environment, including, for example, investing only in the sectors where ethical behavior does not harm competitive position, and rejecting those industries, which are subject to unethical behavior. Such owners are actively involved in CSR activities, which are often categorized as corporate community involvement activities in areas such as education, the arts and sport. Personal involvement of owners in institutionalized and systematic CSR projects of their companies also provide them with the opportunity for self-actualization.

\section{CSR perceptions and practices of non-kin professional executives}

Contrary to owners, all the professional executives were found to be aware of the CSR discourse. Drawing on their managerial cultural and social capital (using capital in Bourdieuian sense; Bourdieu, 1986), non-kin professional executives tend to frame CSR as a strategic choice that can be utilized as a marketing or reputation management tool. Their perceptions are largely characterized by a business-oriented and utilitarian approach, with strong managerial motives, such as compliance with regulatory frameworks, enhancing company reputation and increasing sales. We observed intra-group differences among nonkin professional executives, similar to the case of owners. At one end of the continuum, we identify those professionals who have a basic understanding of, but little interest in CSR (i.e. indifferent professional executives), whilst at the other end are the non-kin professionals who have an advanced holistic understanding of CSR (i.e. value-based enlightened professional executive).

Indifferent non-kin professional executives: The professionals in this group display a limited understanding and practice of CSR, although they are professionally familiar with the concept. In some instances, they do not practice CSR at all as a part of their business activity (B1-1). In addition, non-kin professional executives in this group describe CSR in a detached 
manner and do not demonstrate deep engagement. For example, CSR is sometimes seen as part of the marketing or branding strategy. One of the respondents explained that CSR activities in his company are devolved into distinct brands and merely used as a marketing tool to increase the sales of the firm's different brands. This example illustrates that CSR is seen to have little relevance for the remit of the executive's role apart from being a marginal brand management activity. In the companies where non-kin professional executives display such a limited CSR awareness and commitment, there is also a lack of philanthropic emphasis on CSR. The demographic characteristics of the two executives in this group are similar to those in other groups. They are all university graduates and male.

Corrective-instrumentalist non-kin professional executives: The next group in the continuum is the non-kin executives, who tend to take corrective action through CSR in order to balance the negative externalities borne out by corporate activities. We call this group as corrective-instrumentalists, whose members perceive CSR as a mechanism of compensation for the negative effect of the corporation on the society and the environment (B2-1 on the Table 1). In this group, the harmful environmental impact is the most commonly expressed area of concern that CSR activities aim to address. Professional executives in this group admit that corporations may have negative externalities, such as environmental pollution, and CSR is important to mitigate the harm caused by their activities. In this sense, CSR approach of this group is corrective and reactive in an attempt to compensate for the adverse corporate impact with little proactive commitment. An interesting tendency among this group of executives is the way CSR rhetoric is utilized in order to frame the negative corporate impact in positive terms. The professional executives in this group (2 in total) are university graduates and male and their companies display different background characteristics in terms of size, industry and foreign market exposure. 
Pragmatist non-kin professional executive: Non-kin professionals, who form the next group in our typology, represent the largest majority with five professional top executives, who are all employed by large diversified holding companies. They are all university graduates. The only female professional executive of our sample is in that category. They are motivated by the firm's growth through advanced corporate image activities supported by CSR initiatives. This group is one step ahead in terms of operationalization of CSR and its embeddedness within the business activity compared with the previous two groups. The practices in this group usually stem from a fully pragmatic schema of survival and reputation management. These are self-interested individuals who act upon the principle of pragmatic legitimacy (B31). Given that professionalism inevitably necessitates a highly rationalized conception of business, by converting every single activity into a profit-generation possibility, this group of executives tends to regard CSR as a growth opportunity for the firm. They appear to focus on the transformation of input to mainly economic output with an emphasis on the money spent on each activity and its impact. Their discourses highlight the monetary aspects of their CSR activities. This group of executives see CSR activities as a potential tool to secure their position in the company insofar as CSR accrues benefits for the business. Improved company performance strengthens the relatively precarious position that these executives occupy in the corporation. As a result, their CSR perceptions are more strongly influenced by immediate career concerns compared with that of owners, who are well-anchored by their ownership.

Value-based enlightened non-kin executives: This is the final group in our sample of professional executives, who have a holistic perspective of CSR in the sense that they embrace different stakeholders in the society and they are well aware of their responsibilities towards them. Their perceptions and understandings of CSR are underpinned by their moral 
judgements about socially acceptable actions. All three top executives in this group diverge significantly from the rest of the top executives. They emulate an owner- role, in that they were called upon to undertake the creation and/or development of their companies (and associated foundation, if any) on behalf of a large number of shareholders. Two of them are university graduates and they are all male. The focus on justice and ethics in the company and creating social benefits for society is striking in their discourse and endeavors. It is worth noting that the companies they manage have specific ownership structures. While one company is owned by a foundation, the other two are not affiliated with family businesses and have a large ownership base. Another interesting point is that, compared to owners, their discourse is less focused on society and more focused on internal stakeholders. One of the executives in this group opposed company philanthropic activities, stating that these are deducted from taxes. He maintained that those activities should be personal. Another top executive in this group emphasized the importance of the harmony and satisfaction of the workers and creating value for the society (B4-2)

\section{Comparing owner-executives and professional executives}

The CSR perceptions of owners and professional executives seem to differ considerably. Differences not only appear at the perception level, but also at the level of involvement in CSR projects. Owners are more inclined to consider CSR activities at the societal level, while non-kin professional executives identify themselves with the activity and rationale of managing. They are often limited by the boundaries of the enterprise and geared towards rational and instrumental utilization of CSR. Professional executives tend to take on CSR initiatives that are conceived strategically as conferring competitive advantage on the corporation over its competitors. For example, instances of building schools, museums, nurseries or facilities for the elderly people in their home towns are frequent among owners 
and which is not the case for non-kin executives. They are more interested in CSR communication of the company and its organization. These differences are also attributable to the way in which owners and professional executives identify themselves with the business corporation and its foundations. Owners are highly ideological about their organization in terms of its objectives and its relationships with a diverse set of stakeholders including the society, and they hold the means to orient and direct resources toward the perceived demands of multiple stakeholders. Non-kin professional executives, on the other hand, whilst ideologically identifying with the corporation they manage, they do not have the managerial power in economic capital terms in most cases. They represent their corporations as highly rational individuals with certain kinds of motivation and expertise and strive towards capitalizing on CSR opportunities as they view stakeholder demands as opportunities to be leveraged for the interests of the company (C1-1 and C1-2). This is another example to rationalization aspect of agency, rationally oriented action dominating unconscious motives.

Exploring the CSR perceptions and practices in our research was intriguing, because of the existence of unexpectedly multiple ways, meanings and expectations of CSR, when a comparison of owner- and professional executives was carried out. As owners of the economic capital and granted with exclusive rights in the context of legal and corporate frameworks in Turkey, owner-executives are more empowered in developing and pursuing CSR matters based on their personal preferences and values. Professional executives, on the other hand, exhibit greater levels of knowledge of CSR, but the CSR initiatives they develop tend to be the results of strategic choices to ensure their survival and to enhance their power within the corporation.

Owner-executives emerge as powerful actors with multiple business interests and in close contact with the national and local administrations. As owners of economic capital, they can decide to divert some of the corporate earnings to CSR activities for reputational gains 
and legitimacy building, enhancing relations with administrators and local communities, or for facilitating wider societal change in line with their personal values and ideologies. Strikingly, a substantive segment of the owner-executives has no notion of CSR, and a large majority has a traditional paternalistic approach to CSR. In some cases, traditional and paternalistic approaches to CSR appear to be underpinned by executives' religious beliefs and philanthropic values. However, this does not fully represent 'traditionalism' in CSR. The traditional paternalistic approach to CSR is closely associated with a strategy of establishing and exercising power by owner-executives. This allows scope for highlighting the role of the executive agency in developing CSR approaches and programs. Such paternalistic owners, who form a large majority in our sample, express their executive agency through developing paternalistic (either traditional or institutionalized) approaches to CSR. Thus, related CSR activities become effective instruments of their agency. A result of such a panorama of executives indicates that the CSR definition, as it is conceptualized in managerial approaches, is not fully shared in Turkey, particularly among owner-executives who transpose their traditional perception of CSR, mostly as social aid driven by cultural or religious motives, onto the functions of their capitalistic enterprise. This should not be only seen as a simple lack of knowledge of owner-executives about the imported definition of CSR, which is also an important factor, but a tactical preference in an economy, which is both globalizing and remaining attached, in some respects, to the traditional social relationships.

Professional executives, on the other hand, need to seek legitimacy for their CSR decisions as they do not own the economic capital and thus lack the authority to allocate firm assets at their own discretion. As a result, although they have awareness of CSR, they tend to perceive it as an instrumental issue, or a managerial tool, often without culturally-oriented values. 


\section{DISCUSSION AND CONCLUSION}

As noted, implications of ownership on CSR related agency of executives is under-researched (Angus-Leppan, Metcalf, and Benn, 2010; Arora and Dharwadkar, 2011; Mellahi, Frynas, Sun, Siegel, 2016; Waldman and Siegel, 2008) and often the analysis remained at individual level focusing on the influence of executive values and leadership styles on CSR agency (Groves and LaRocca, 2011; Waldman et al., 2006; Du et al., 2013; Vlachos et al. 2013). In this paper, we move this literature forward by focusing our attention into the influence of ownership (or lack of) on the CSR-related agency of executives as embedded in the specific societal context of Turkey. In this way, we move the scholarly debate on the role of executive agency in CSR practice beyond individual-level explanations towards a relational explanation that accounts for both individual and societal circumstances. Thus, our paper bridges the literatures on political CSR (Scherer and Palazzo, 2007) and on CSR practice and CSRrelated agency.

Our endeavor is informed by Giddens' (1989) conceptualization of agency as an outcome of the interplay of structural and individual influences. Very much like Giddens' (1989) agents, owner- and professional executives exercised CSR-related agency based on their (sometimes conscious but often unconscious) interpretations of rules, and values that are effective in their context and aligned with their ownership of economic resources. For example, we found that the CSR practice seems to vary in accordance with the tendency of the firm to grow and become internationally operating. In large-scale and globally integrated corporations, CSR activities produce indirect political power, while relatively local executives seek a more traditional paternalistic power. Yet executives’ agentic capacity is mostly situated on their possession of economic capital. It should be noted that ownership type (Dam and Scholtens, 2012) and equity ownership concentration (Faller and Knyphausen-Aufseb, 2016) also affect CSR engagement. Our empirical study has allowed us to generate insights into 
varying perceptions and practices of CSR activities among executives, differentiated along the lines of ownership by presenting a typology of CSR agency that accounts for structural and objective circumstances (e.g. ownership) and personal values and strategies (Figure 2). For example, for paternalist and value-based owner-executives, CSR commitment and awareness are partially an outcome of early childhood socialization and family values. For instance, these executives often have family member (e.g. father, grandfather or grandmother) with strong social values and active community involvement. Even when CSR appears to be a pragmatically-oriented activity, its rational use nevertheless necessitates a cultural acquisition of a CSR approach that is embodied in attitudes and activities. These owners also appear to be more inclined to express their vision at the societal level. The focus on the society becomes stronger as we move to the last two categories, which are labelled as paternalistic and valuebased owner-executives. In fact, this focus of CSR vision also constitutes the most striking difference between the approaches of owners and non-kin professional executives, whose vision is seemingly restricted to enterprise level.

While owners present a diverse set of motives in their engagement with CSR, ranging from simplistic philanthropic drives or pursuing a simple business opportunity to a broader and holistic perspective on business-society relationships creating pluralistic definitions of value for multiple stakeholders with ultimate aims of building and sustaining institutional legitimacy of the corporation; professional executives treat CSR rationally and instrumentally so that CSR projects manifest in strategic and tactical terms for better organizational performance achieved by effective management of capital and stakeholder relationships. The main drive of professional executives is a double-faced instrumentalism: On the one side they try to apply to the specific conditions of their firm, an imported, academically thought managerial doctrine, which consists on giving priority to the good social image of the trademark represented by the corporate activity, and, on the other, they tend to convert all 
administrative assets into meticulously conceived instruments of personal and institutional power. In opposition to such an instrumental attitude, the underlying motive of the owners, though they are manifested in a much more varied typology, is still to keep a part of traditional authority, the paternalistic mechanism of both social security and control, which at the end harvest a considerable reputation.

Broader definitions of CSR allow for illuminating distinctions between different types of corporate and managerial responses and motivations (Dunfee, 2013). Our empirical study has generated large and rich data, enabling us to create a typology of executives according to their CSR approaches. At the basic level, we diagnosed that some executives have no notion of CSR. Certain others, on the contrary, are not only fully aware of the CSR notion, but they see it as having a role in driving societal change or in promoting a certain vision of society. Developing an understanding of CSR by owner-executives is not solely a function of structural circumstances such as expansion and growth of the enterprise and business diversification. Their personal trajectory and cultural dispositions shape their understanding of the concept, and therefore their stance. Some owner-executives, have a larger vision of CSR and use it to affect social, political and economic change, converging with the political CSR perspective of Scherer and Palazzo (2007, 2011). At the heart of this wider scope in embracing CSR lies the pursuit of legitimacy through a sense of dialogue with multiple stakeholders (Hanlon, 2009). For these owner-executives, CSR activities go beyond the ordinary philanthropy undertaken by economic actors. Instead, CSR applications transcend boundaries of corporate objectives and traditional acts of social support and community involvement. Rather, they form a way for political involvement without being part of the established politics. Therefore, the logic of justification for CSR, in the case of ownerexecutives, tends to transcend boundaries between economic, ethical, political and social dimensions of CSR. 
Highlighting the significant variations between owner- and professional executives, we argue that the latter, having a certain consciousness of CSR, tend to approach it as a strategic choice which is the most rational course of action given the rules and resources that inform their CSR practice. The large majority of professional executives in our sample are identified as pragmatists. Adopting an instrumentalist approach, they are more in tune with the business case for CSR and emphasize business performance and a utilitarian view of CSR as a mechanism, or simply as another managerial tool. They either engage in CSR activities for better company performance, or to negate the adverse impacts of the corporation's actions, rather than being driven by a commitment to social betterment or acting in accordance with what is fundamentally believed to be the right thing to do (Arvidsson, 2010). Some of these executives consider CSR as a public relations tool and leave it to the discretion of the marketing department. Professional executives in larger companies take a more institutionalized approach to developing CSR programs, but still depart from a mainly pragmatic premise of CSR, with full awareness of its benefits to the company. Even being ethical is conceived in relation to power to handle the business and its potential contribution to the success of the company. This reiterates importance of executive agency, as a composite construct underscored by possession of capital and interlocking elements of power and reflexive monitoring, rationalization and motivation of action, as Giddens (1989) put forward in his dialectical matrix of agency, which we introduced earlier in the paper.

The degree of awareness observed among professional executives should be understood, not in terms of personal interests or cultural dispositions, but rather based on the fact that they are situated in relatively precarious positions in comparison to the owner. The difference between owners and professionals is also a matter of identification with the business corporation and its foundations. Professionals ideologically identify with the corporation they manage, but in most cases, they do not own the economic capital, nor do 
they have underlying control of it. They are representative of the corporation, as wellequipped and highly rational individuals with certain kinds of managerial agency and expertise. Consequently, CSR is perceived by the professional executives as an asset that should be rationally and instrumentally utilized, while owner-executives present a more varied set of motives in their involvement with CSR matters. This is an important finding for CSR research because it redirects our attention back to the conditions under which CSR can become a priority for executives depending on their agentic position open to them as a function of their ownership status.

Our study is positioned within the growing literature on CSR in emerging markets. As business organizations are embedded in national institutions and a web of contextual relationships between stakeholders, CSR is a culturally, socio-economically, legally and ideologically bounded phenomenon. Various combinations of state regulations, industrial norms, stakeholder dynamics, including civil organizations, community groups may bring about different CSR approaches and applications (Campbell, 2007; Yin and Zhang, 2012). CSR practices in emerging economies are contingent upon the institutional structures in such countries (Visser, 2008; Newell and Frynas, 2007; Jamali and Sidani, 2012; Jamali, Karam, Yin and Soundararajan, 2017; Pisani, Kourula, Kolk and Meyjer, 2017). Therefore, transferability of research findings and frameworks drawn in the developed world to developing countries has been critiqued by many scholars (Jamali, 2010; Jamali and Neville, 2011; Kolk and Lenfant, 2010; Muller and Kolk, 2008; Visser, 2008). For example, as our research has also confirmed, philanthropy appears to be a prevailing form of CSR expression in the developing world due to entrenched cultural norms and values (Chapple and Moon, 2005; Ibrahim, Karatas-Ozkan and Jamali, 2012; Jamali and Neville, 2011) often embodied by religious frameworks and expectations (Visser, 2008; Jamali and Neville, 2011). 
Although studies on CSR in countries with emerging economies indicate some specificities, the Turkish case presents distinct particularities due to the complex sociological characteristics of Turkey. First, we should underline that the notion of 'social responsibility' manifests itself in a vast variety of frameworks, which indicates on the one side the lack of corporately organized form of the concept, and on the other, the predominance of a generalized mind of transition, from traditionally-oriented mechanisms of social solidarity to rationally conceived one. As in the classical analysis of Durkheim, a society mostly dominated by agrarian activities where the ties between individuals are historically determined, the rationale of solidarity required for such a structure is the mechanical one (Durkheim, 2013). This means that human relations are regulated within a community, on the mutual control and help, which places the individuals who are economically in well-being at the position of an informal mechanism of social security. As Turkey is a country in a multiple transition from agrarian/traditional to both industrial and post-industrial modes of production in a relatively short period, social values and relations present a panoply of conflicts and contradictions, together with surviving forms of traditional residues, even in modified forms. The concept of social responsibility is one of the most salient functions in a family-firm entrepreneurship, which represents typically the extensions of traditional relations into modern managerial organizations. Second, Islamic doctrine of social aid, the zakat mechanism prevails as the clear majority of the population is Muslim. Zakat is a form of obligatory giving, based on total income and value of one's possessions, in Islam. In the Turkish context, zakat tends to take a form of private and charitable contribution to poor. This religious rule dictating the sharing of the wealth with the needy has become a tradition with also repercussions on the business world. Furthermore, our study was able to trace back some of the more traditional forms of CSR activities to long before the introduction of the imported concept of CSR. 
Our study has moved forward the scholarly debate on CSR by unpacking the impact of the ownership status on the CSR agency (i.e. practices and perceptions) of executives. Our findings enabled us to develop a typology of CSR agency of owner- and professional executives. This forms the first and core contribution of our study. Our study also enhances our understanding of the relationship between CSR and executive agency in an emerging country context, which remains understudied. Emerging country contexts often present environments whereby CSR remains to be an imported concept with insufficient understandings and grounds of justification for a multitude of applications. Understanding managerial motives and key drivers for CSR perspectives and practices in such contexts is of paramount importance. The final contribution of the paper stems from the richness of qualitative evidence collected and analyzed through rigorous procedures. Disconnect between rhetoric and reality, theory and evidence is often a source of criticism in CSR research. This article presents original evidence on both CSR perceptions and CSR practices of owner- and professional executives. Hence, our study highlights the importance of introducing selfreflection into the CSR approaches in order to unearth assumptions held by both owner- and professional executives on what CSR means and why is it worth pursuing if at all. An examination of their own CSR motives and dispositions as well as their agency as executives can help them develop more responsible leadership and carry out more proactive outlook to societal expectations. Responsiveness developed out of questioning entrenched values, motivations, drivers of social responsibility as well as managerial power can contribute to advancing CSR techniques.

Even though the unequal samples reflect the actual representations at the upper echelons in Turkish companies, the quantitative disequilibrium between owner- and professional executives is an important limitation of our study. With a greater proportion of professional executives within a relatively balanced set of interviewees, the conceptual 
comparison between both universes would be more accurate. Future studies should endeavor to examine the topic from different angles, such as gender, age and educational affiliation. There is scope for comparing and contrasting the perceptual differences between female and male owner- and professional executives, but also those of older and younger generations of executives. Equally, educational profile, and hence cultural capital and cognitive schema of executives could be an interesting dimension to study. Finally, the CSR scholarship would benefit from research that demonstrates cross-cultural differences in the perception and approaches of owner- and professional executives.

\section{REFERENCES}

Alakavuklar, O.N., Kılıçaslan, S. and Öztürk, E.B., 2009. Türkiye'de hayırseverlikten kurumsal sosyal sorumluluğa geçiş: Bir kurumsal değişim öyküsü.(The transition from philanthropy to CSR in Turkey: A story of institutional change) Yönetim Araştırmaları Dergisi, 9 (2):12-53.

Alvesson, M. and Ashcraft, K. L. 2012. Interviews, in (Eds) Symon, G. and Cassell, C. Qualitative Organizational Research: Core Methods and Current Challenges. Sage Publications, Thousand Oaks.

Angus-Leppan, T., Metcalf, L. and Benn, S., 2010. Leadership styles and CSR practice: An examination of sensemaking, institutional drivers and CSR leadership. Journal of Business Ethics, 93:189-213.

Ararat, M., 2008. A development perspective for ‘corporate social responsibility’: Case of Turkey. Corporate Governance, 8: 271-285.

Arora, P. and Dharwadkar, R., 2011. Corporate governance and corporate social responsibility (CSR): The moderating roles of attainment discrepancy and organization slack. Corporate Governance: An International Review, 19 (2):136-152. Arvidsson, S., 2010. Communication of corporate social responsibility: A study of the views 
of management teams in large comparison. Journal of Business Ethics, 96 (3):339-354.

Ascigil, S., 2003. Corporate social responsibility in Turkey. Türkiye Ekonomik ve Sosyal Etütler Vakfi (TESEV) Araştırması.

Bacharach, S. B., Bamberger, P., \& McKinney, V. 2000. Boundary management tactics and logics of action: The case of peer-support providers. Administrative Science Quarterly, 45(4), 704-736.

Baumann-Pauly, D., Wickert, C., Spence, L. J., \& Scherer, A. G. 2013. Organizing corporate social responsibility in small and large firms: Size matters. Journal of Business Ethics, 115(4), 693-705.

Besser, T. L. 2012. The consequences of social responsibility for small business owners in small towns. Business Ethics: A European Review, 21(2), 129-139.

Boyatsis, R. E., 1998. Transforming qualitative information. London: Sage. Bourdieu, P. 1986. The forms of capital. In: Richardson JG (ed) Handbook of Theory and Research for the Sociology of Education. New York: Greenwood, pp. 241-258.

Boyatzis, R. E. (1998). Transforming Qualitative Information: Thematic analysis and Code Development. Sage Publications, Thousand Oaks.

Brik, A. B., Rettab, B. and Mellahi, K., 2011. Market orientation, corporate social responsibility, and business performance. Journal of Business Ethics, 99:307-324.

Buğra, A., 1994. State and business in modern Turkey: A comparative study. Albany: State University of New York Press.

Bulut, D. and Yumrukaya, C.B., 2009. Corporate social responsibility in culture and art. Management of Environmental Quality: An International Journal, 20 (3): 311-320.

Cabeza-García, L., Fernández-Gago, R., \& Nieto, M. 2017. Do Board Gender Diversity and Director Typology Impact CSR Reporting?. European Management Review. https://doi.org/10.1111/emre.12143. 
Campbell, J. L. 2007. Why would corporations behave in socially responsible ways? An institutional theory of corporate social responsibility. Academy of Management Review, 32 (3):948-967.

Carrington, M., Zwick, D., and Neville, B. 2018. Activism and Abdication on the Inside: The Effect of Everyday Practice on Corporate Responsibility. Journal of Business Ethics, 1-27. Carroll, A. B., 1999. Corporate social responsibility: Evolution of a definitional construct. Business and Society, 38: 268-294.

Carroll, A. B., 1991. The pyramid of corporate social responsibility: Toward the moral management of organizational stakeholders. Business Horizons, 34:39-48.

Carroll, A. B., 1981. Business and society: Managing corporate social performance. Boston: Little Brown.

Carroll, A. B., 1979. A three-dimensional conceptual model of corporate social performance. Academy of Management Review, 4: 497-505.

Caroll, A. B. and Bucholtz, A. K. 2006. Business and Society: Ethics and Stakeholder Management. 6E International Student Edition. Mason, Ohio: Thomson.

Chapple, W. and Moon, J. 2005. Corporate social responsibility in Asia: A seven-country study of CSR website reporting. Business and Society, 44: 415-441.

Dam, L., \& Scholtens, B. 2012. Does ownership type matter for corporate social responsibility?. Corporate Governance: An International Review, 20(3), 233-252. Deakin, S. and Whittaker, H. D., 2007. Re-embedding the Corporation? Comparative perspectives on corporate governance, employment relations and corporate social responsibility. Corporate Governance: An International Review, 15: 1-4. De Certaeu, M. (2002). L'invention du quotidien, Tome 1, Arts de faire, Paris: Editions Gallimard. 
De Cremer, D. van Dick, R., Tenbrunsel, A., Pillutla, M., and Murnighan, J. K. 2011. Understanding ethical behaviour and decision making in management: A behavioural business ethics approach. British Journal of Management, 22: 1-4.

Del Baldo, M., 2010. Corporate social responsibility and corporate governance in Italian SMEs:The experience of some 'spirited businesses'. Journal of Management and Governance, 16: 1-36.

Djelic, M. L., \& Etchanchu, H. 2017. Contextualizing corporate political responsibilities: Neoliberal CSR in historical perspective. Journal of Business Ethics, 142(4), 641-661.

Du, S., Swaen, V., Lindgreen, A. and Sen, S. 2013. The roles of leadership styles in corporate social responsibility. Journal of Business Ethics, 114:155-169.

Du, S., Bhattacharya, C. B. and Sen, S. 2011. Corporate social responsibility and competitive advantage: Overcoming the trust barrier. Management Science, 57: 1528-1545.

Durkheim, E. 2013. La division sociale du travail, Paris: Broché.

Elsayed, K., 2010. A multi-theory perspective of board leadership structure: What does the Egyptian corporate governance context tell us. British Journal of Management, 21: 80-99. Epstein, E. M., 1987. The corporate social policy process:Beyond business ethics, corporate social responsibility, and corporate social responsiveness. California Management Review, 29: 99-114.

Ertuna, B. and Tükel, A., 2009. Türkiye'de KSS uygulamaları: Geleneksel ve küresel arasında (CSR practices in Turkey: Between traditional and global). Yönetim Araştırmaları Dergisi, 9 (2): 54-82.

Fassin, Y., Werner, A., Van Rossem, A., Signori, S., Garriga, E., von Weltzien Hoivik, H., \& Schlierer, H. J. 2015. CSR and related terms in SME owner-managers' mental models in six European countries: national context matters. Journal of Business Ethics, 128(2), 433-456. 
Fassin, Y., Van Rossem, A. and Buelens, M., 2011. Small-Business owner-managers’ perceptions of business ethics and CSR related concepts. Journal of Business Ethics, 97: 1-29. Giddens, A., 1989. The Constitution of Society. Cambridge: Polity Press.

Gioia, D. A., Corley, K. G., \& Hamilton, A. L. 2013. Seeking qualitative rigor in inductive research: Notes on the Gioia methodology. Organizational Research Methods, 16(1), 15-31. Groves, K. S., \& LaRocca, M. A. 2011. An empirical study of leader ethical values, transformational and transactional leadership, and follower attitudes toward corporate social responsibility. Journal of Business Ethics, 103 (4), 511-528.

Hofman, P. S., Moon, J., \& Wu, B. 2017. Corporate social responsibility under authoritarian capitalism: Dynamics and prospects of state-led and society-driven CSR. Business \& Society, 56(5), 651-671.

Hurriyet 2011. Nüfusumuzun yüzde 92.3’ü klasik müzik dinlemiyor, 23.11.2011. Ibrahim, S., Jamali, D., \& Karatas-Ozkan, M. 2012. Corporate social responsibility (CSR) in Small and Medium-Sized Enterprises: A developing country perspective. In Social and Sustainable Enterprise: Changing the Nature of Business (pp. 167-192). Emerald Group Publishing Limited.

Isaksson, L., Kiessling, T. and Harvey. M. 2014. Corporate social responsibility: Why bother? Organizational Dynamics, 43: 64-72.

Jamali, D. (2010) The CSR of MNC subsidiaries in developing countries: Global, local, substantive or diluted? Journal of Business Ethics, 93: 181-200.

Jamali, D. and Neville, B. 2011. Convergence versus divergence of CSR in developing countries: An embedded multi-layered institutional lens. Journal of Business Ethics, 102: 599621. 
Jamali, D. and Sidani, Y. 2012. Introduction: CSR in the Middle East: Fresh perspectives. In D. Jamali and Y. Sidani (Eds.) CSR in the Middle East: Fresh Perspectives. Palgrave, pp. 111.

Jamali, D., Karam, C., Yin, J., \& Soundararajan, V. 2017. CSR logics in developing countries: Translation, adaptation and stalled development. Journal of World Business, 52(3): 343-359.

Jenkins, H., 2006. Small business champions for corporate social responsibility. Journal of Business Ethics, 67:.241-256.

Jiang, F., Zalan, T., Herman, H. M., \& Shen, J. 2018. Mapping the relationship among political ideology, CSR mindset, and CSR strategy: A contingency perspective applied to Chinese managers. Journal of Business Ethics, 147(2): 419-444.

Jiraporn, P. and Chintrakarn, P. 2013 How do powerful CEOs view corporate social responsibility?: An empirical note. Economics Letters, 119: 344-347.

Kemper, A., \& Martin, R. L. 2010. After the fall: The global financial crisis as a test of corporate social responsibility theories. European Management Review, 7(4), 229-239. Kolk, A. and Lenfant, F. 2010. MNC reporting on CSR and conflict in Central Africa. Journal of Business Ethics, 93: 241-255.

Küskü, F. and Bay, E., 2012. İsteğe bağl1 kurumsal sosyal sorumluluk hareketleri: Görünürde hayırseverlik (Voluntary CSR behaviors: Appearing philanthropic). Amme İdaresi Dergisi, 45:51-75.

Lähdesmäki, M. 2012. Construction of owner-manager identity in corporate social responsibility discourse. Business Ethics: A European Review, 21(2), 168-182.

Legrand, C., Al Ariss, A., \& Bozionelos, N. 2018. Migrant CEOs: Barriers and Strategies on the Way to the Top, European Management Review, https://doi.org/10.1111/emre.12166. 
Lincoln, Y. S., \& Guba, E. G. 1985. Naturalistic Inquiry, Sage Publications.

Matten, D. and Moon, J., 2008. 'Implicit' and 'explicit' CSR: A conceptual framework for a comparative understanding of corporate social responsibility. Academy of Management Review, 33:404-424.

Mellahi, K., Frynas, J. G., Sun P., \& Siegel, D. 2016. A review of the nonmarket strategy literature: Toward a multi-theoretical integration. Journal of Management, 42:143-173. Morgan, G., Quack, S., \& Hirsch, P. (Eds.). 2015. Elites on Trial. Emerald Group Publishing. Muller, A. and Kolk, A. (2009) CSR performance in emerging markets: Evidence from Mexico. Journal of Business Ethics, 85:325-337.

Murillo, D. and Lozano, J. M., 2006. SMEs and CSR: An approach to CSR in their own words. Journal of Business Ethics, 67:227-240.

Myers, M. D. 2013. Qualitative research in Business and Management. Sage Publications, Thousand Oaks.

Newell, P. and Frynas, J. G. 2007. Beyond CSR? Business poverty and social justice: An introduction. Third World Quarterly, 28: 669-681.

Patton, M. Q. 2015. Qualitative Research and Methods: Integrating Theory and Practice.Sage Publications, Thousand Oaks.

Perrini, F., 2006. SMEs and CSR theory: Evidence and implications from an Italian perspective. Journal of Business Ethics, 67:305-316.

Pisani, N., Kourula, A., Kolk, A., \& Meijer, R. 2017. How global is international CSR research? Insights and recommendations from a systematic review. Journal of World Business, 52(5): 591-614.

Robertson, D. C., 2009. Corporate social responsibility and different stages of economic development: Singapore, Turkey and Ethiopia. Journal of Business Ethics, 88:617-633. 
Russo, A. and Tencati, A., 2008. Formal vs. informal CSR strategies: Evidence from Italian micro, small, medium-sized and large firms. Journal of Business Ethics, 85:339-353.

Scherer, A. G. and Palazzo, G., 2007. Towards a political conception of corporate responsibility - business and society seen from a Habermasian perspective. Academy of Management Review, 32:1096-1120.

Scherer, A.G. and Palazzo, G. 2011. The new political role of business in a globalized world: A review of a new perspective on CSR and its implications for the firm, governance, and democracy. Journal of Management Studies, 48:899-931.

Selekler-Göksen, N. \& Üsdiken, B. 2001. Uniformity and diversity in Turkish Business Groups: Effects of scale and time of founding. British Journal of Management, 325-340. Sison, A. J. G., 2009. From CSR to corporate citizenship: Anglo-American and continental European perspectives. Journal of Business Ethics, 89:235-246.

Symon, G., and Cassell, C. (Eds.). 2012. Qualitative organizational research: core methods and current challenges. Sage Publications.

Tafel-Viia, K. and Alas, R., 2009. Differences and conflicts between owners and top managers in the context of social responsibility. Inžinerinė Ekonomika-Engineering Economics, 4:86-94.

Visser, W. 2008. Corporate Social Responsibility in developing countries. In A. Crane, A.McWilliams, D. Matten, J. Moon and D. Siegel (Eds.), Oxford Handbook of Corporate Social Responsibility, Oxford: Oxford University Press, pp. 473-479.

Vlachos, P. A., Panagopoulos, N. G., and Rapp, A. A. 2013. Feeling good by doing good: Employee CSR-induced attributions, job satisfaction, and the role of charismatic leadership, Journal of Business Ethics, 118:577-588.

Waldman, D. and Siegel, D. S., 2008. Defining the socially responsible leader. The Leadership Quarterly, 19: 117-131. 
Waldman, D. A., Siegel, D. and Javidan, M., 2006. Components of CEO transformational leadership and corporate social responsibility. Journal of Management Studies, 43:1703-1725. Wood, D. J., 1991. Corporate social performance revisited. Academy of Management Review, 16:691-718.

Yin, J. and Zhang, Y. 2012. Institutional dynamics and corporate social responsibility (CSR) in an emerging country context: Evidence from China. Journal of Business Ethics, 111:301316.

Yamak, S. 2007. Kurumsal sosyal sorumluluk kavramının gelişimi (The evolution of corporate social responsibility). Istanbul:Beta.

Yamak, S. 1998. Türkiye'de yönetici elitlerin eğitim durumu: 80'lerden 90'lara neler değişti?. Amme İdaresi Dergisi, 31: 65-78.

Yamak, S.\& Ertuna, B. 2017. A Primer in Corporate Governance:Turkey. Business Experts Collections Press/Momentum Press: NY

Yamak, S. and Ertuna, B., 2012. Corporate governance and initial public offerings in Turkey. In: A. Zattoni and W. Q. Judge, eds. Corporate Governance and Initial Public Offerings (IPOs): An International Perspective. Cambridge: Cambridge University Press, pp.470-498. Yamak, S., Ertuna, B. \& Bolak, M. 2006. Sahiplik dagiliminin birlesik liderlik yapisi üzerine etkileri. (The impact of ownership structure on duality) Yönetim Araştırmaları Dergisi, 6: 85106. 
Table 1. Exemplary quotes for intra and intergroup differences

\begin{tabular}{|c|c|}
\hline \multirow{2}{*}{ Groups } & \\
\hline & Intra-group differences \\
\hline \multicolumn{2}{|l|}{ Owners } \\
\hline & A1.Ignorant/insensitive owners \\
\hline & $\begin{array}{l}\text { A1-1"[During the crisis period] we fired our workers. We fired 30-40\% of our } \\
\text { workers. We reduced our production ...We investigated the ways of profitable } \\
\text { production... We stopped high energy-consuming machineries. We used the new } \\
\text { ones which consume less energy. We planned to use the old, high energy- } \\
\text { consuming machinery when the business would re-boost and we would have } \\
\text { more money." (Male, 46, owner of a large industrial firm) }\end{array}$ \\
\hline & A2.Pragmatist owner \\
\hline & $\begin{array}{l}\text { A2-1"We provide grants to the children of our workers as well as to the children } \\
\text { of the state agency employees from whom we get our business contracts." } \\
\text { (Male, 50, owner of a group of companies) }\end{array}$ \\
\hline & $\begin{array}{l}\text { A2-2"Along with his business he [the founder of the company] used to be very } \\
\text { active socially. He constructed schools. ... Once he believed that communism } \\
\text { would take over Turkey and supported the construction of mosques. Later he } \\
\text { thought that the army would save the country and helped with the construction } \\
\text { of military facilities." (Male, 55, owner of a large industrial firm) }\end{array}$ \\
\hline & A3. Paternalist owner \\
\hline & $\begin{array}{l}\text { A3-1"Well, in our corporation, there is no such thing defined as a social } \\
\text { responsibility project. But we, as partners and associates, my uncles, my cousins } \\
\text { etc., we have an agreement for spending a certain amount of money for } \\
\text { religious aid. [...] The company has no written policy or code of conduct for CSR. } \\
\text { Such funding, is, however, reserved for such purposes. People in the community } \\
\text { come to us with various requests such as if we can contribute towards } \\
\text { construction of a mosque or school. . [...] This type of social project is } \\
\text { acknowledged in law for tax-sharing purposes. However, we did not declare it } \\
\text { as CSR policy or initiative. [The company should not take profit due to this } \\
\text { activity] We simply respond to social needs as identified by our community." } \\
\text { (Male, 43, owner of a large manufacturing firm) }\end{array}$ \\
\hline & $\begin{array}{l}\text { A3-2"For the matter of social responsibility, it means that we have the material } \\
\text { and moral responsibility for the professional life of the people. From a certain } \\
\text { point, I see workers employed in our companies as our children. This year we } \\
\text { established a pool of social responsibility projects. We asked all of our workers } \\
\text { to send their ideas. [...] Under the leadership of two of our colleagues, we } \\
\text { managed this pool under a foundation. [...] We have, very soon, our anniversary } \\
\text { of the 30th year of foundation." (Female, 48, owner of a group of companies) }\end{array}$ \\
\hline & A4-Value based owner \\
\hline & $\begin{array}{l}\text { A4-1 "What one produces should, first of all, address human needs. Whatever } \\
\text { the firm produces should offer a solution to social needs, which should be the } \\
\text { needs of the community overall, rather than the needs of a small minority. A } \\
\text { certain percentage of the profit accrued from every product should be invested } \\
\text { for a certain social purpose. This could be in the form of taking care of nature } \\
\text { or meeting needs of disadvantaged groups...In our philosophy, being ethical } \\
\text { cuts across all aspects of life: Individuals should be ethical; products should be }\end{array}$ \\
\hline
\end{tabular}




\begin{tabular}{|c|c|}
\hline & $\begin{array}{l}\text { ethical; so should be the institutions." (Male, 39, owner of a group of } \\
\text { companies) }\end{array}$ \\
\hline & $\begin{array}{l}\text { A4-2 "For example, we educate our employees for human rights: What is my } \\
\text { right? What is yours? We can attain democracy only through education. This is } \\
\text { not compulsory. We do that in the factories. [...] Also, I went through a change; } \\
\text { a real change. This is a kind of prayer. Some go to Mecca as pilgrims; this is the } \\
\text { same thing for me. I have carried out several social projects in Anatolia. I am } \\
\text { working with women. [...] My mission is to improve the conditions of women in } \\
\text { Turkey. I devote considerable time to these activities by activating different } \\
\text { chambers of commerce, universities and NGOs in different cities. I organize my } \\
\text { business along this mission." (Female, 60, owner of a holding company) }\end{array}$ \\
\hline \multicolumn{2}{|l|}{$\begin{array}{l}\text { Non-kin } \\
\text { Professional } \\
\text { Executive } \\
\end{array}$} \\
\hline & B1. Indifferent non-kin professional executives \\
\hline & $\begin{array}{l}\text { B1-1"We do not have much CSR activity. We only provide traineeships for the } \\
\text { students and we pay them even though we are not obliged to do so." (Male, } 42 \text {, } \\
\text { CEO of an industrial company) }\end{array}$ \\
\hline & B2. Corrective-instrumentalist non-kin professional executives \\
\hline & $\begin{array}{l}\text { B2-1"We have constructed waste treatment facilities with the provocation of } \\
\text { the municipality. The waste we create is harmful for the environment if we } \\
\text { dump it directly into the sea or to the soil. Before we used to pay a man by } \\
\text { telling him to obliterate it in any way he wishes... The furnaces produce } 1000 \mathrm{cc} \\
\text { heat and we release a heat of } 300 \text { cc from our chimneys. We have investigated } \\
\text { how we could use this energy. We visited energy plants in Switzerland. We had } \\
\text { the idea of drying the waste with the outgoing heat from the chimneys. That } \\
\text { way we obtained a } 2000 \text { calorie combustible. Dried waste which is turned into } \\
\text { a combustible is in turn used in our furnace as an energy source." (Male, 70, } \\
\text { CEO of an industrial company) }\end{array}$ \\
\hline & $\begin{array}{l}\text { B2-2"Our social responsibility is measured by our respect for the environment. } \\
\text { This is very important. [...] It is social responsibility with its filtering [system]. } \\
\text { Besides, personally [I support] all the research activity on the air pollution of } \\
\text { the cars. And the electrical car is one of the ultimate objectives." (Male, 54, CEO } \\
\text { of a large industrial company) }\end{array}$ \\
\hline & B3. Pragmatist non-kin executives \\
\hline & $\begin{array}{l}\text { B3-1"We have a corporate communication department executing our social } \\
\text { responsibility projects. For this, we also use external support. We have a } \\
\text { promotions agency, with which we work together, and all our investments are } \\
\text { in education and culture. I think we have five schools that we constructed and } \\
\text { take care of. We didn't only construct them and let them go; but we delivered } \\
\text { them to the [Ministry of] National Education. We also constructed a section of a } \\
\text { technical high school conceived by the X [the name of the city] Chamber of } \\
\text { Commerce. Now we are constructing a cultural centre in Z [the name of the } \\
\text { city]. " (Male, 66, CEO of a large holding company) }\end{array}$ \\
\hline & B4. Value-based enlightened non-kin executives \\
\hline & $\begin{array}{l}\text { B4-1"We have always been very honest with each shareholder and recorded all money } \\
\text { received from each shareholder and paid taxes...... We have never fired employees } \\
\text { during economic crises and we are still among the largest companies." (Male, 60, top } \\
\text { executive of a group of companies) }\end{array}$ \\
\hline
\end{tabular}




\begin{tabular}{|l|l|}
\hline & \multicolumn{1}{|l|}{} \\
\hline & $\begin{array}{l}\text { B4-2"We emphasize a peaceful work atmosphere where our employees enjoy } \\
\text { serenity. We do not hire competitive managers who could harm this } \\
\text { atmosphere. Our company operates on a key principle of motivating and } \\
\text { satisfying employees at higher levels of personal development and self- } \\
\text { actualization. This precedes financial rewards and satisfaction. We protect our } \\
\text { employees and make them feel that they belong to our 'community' and they } \\
\text { are key stakeholders in achieving the well-being of the organization, which will } \\
\text { in turn benefit them even more. Above all, we make sure that our surplus is } \\
\text { invested for good cause. We pay our tax first and after fulfilling our tax } \\
\text { obligations, we make decisions to spend some of our surplus for social causes } \\
\text { and do not count this expense as a taxable expense, contrary to those } \\
\text { companies which practise this as such in order to gain tax advantage." (Male, } \\
\text { 64, CEO of a holding company) }\end{array}$ \\
\hline Owners & $\begin{array}{l}\text { C. Inter-group differences } \\
\text { of the schooling of the girls and the other is about preventing the violence } \\
\text { within the family. (Female, 44, owner of a large holding company) }\end{array}$ \\
\hline $\begin{array}{l}\text { Non-kin } \\
\text { Executives }\end{array}$ & $\begin{array}{l}\text { C1-2 We manufacture small sized packages for our female customers to help } \\
\text { them carry easily and we train our customers about efficient use of water } \\
\text { (Female, 60, CEO in a large manufacturing company). }\end{array}$ \\
\hline
\end{tabular}


Figure 1. Coding scheme based on Gioia's (2012) methodology

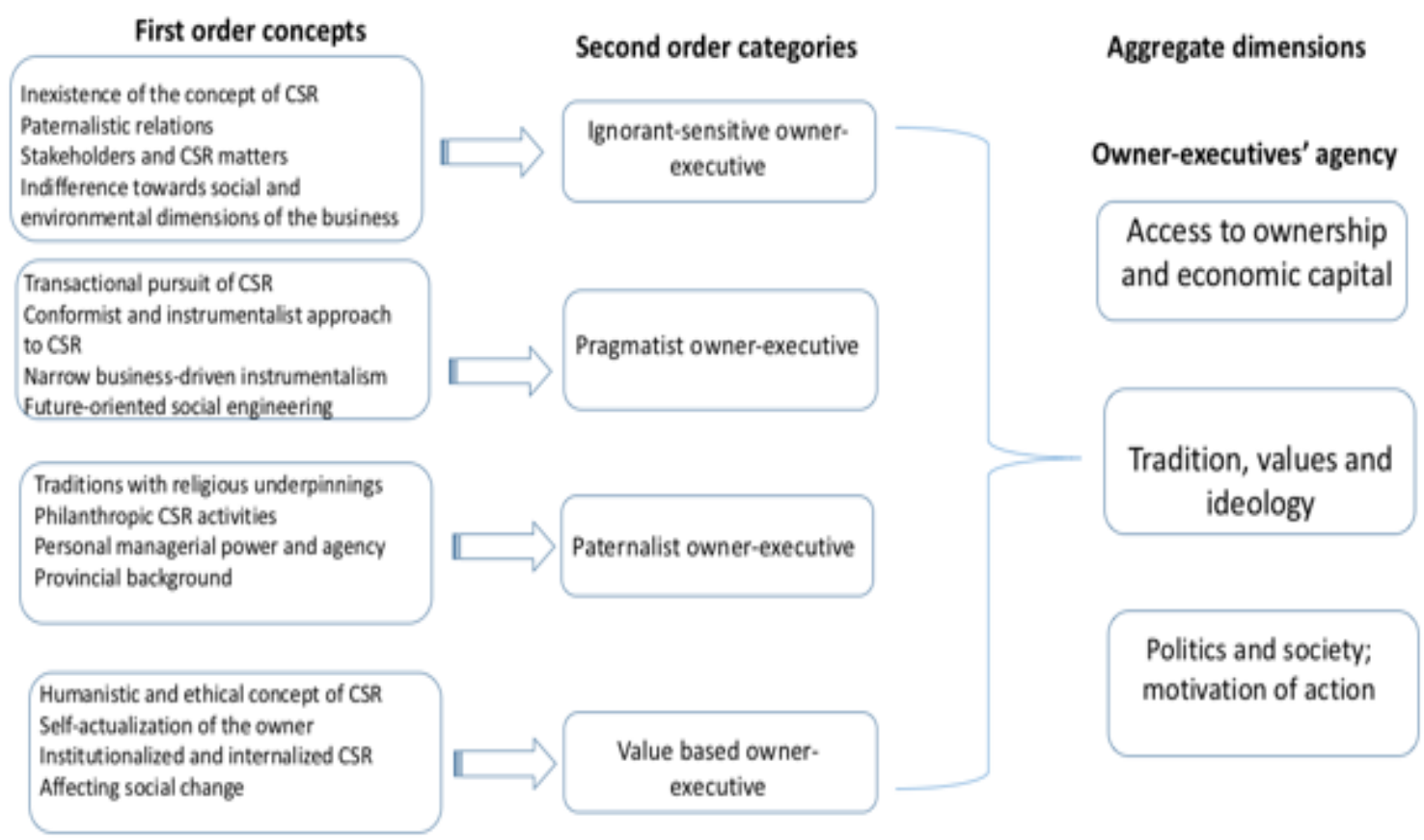

Limited and underdeveloped understanding of CSR

Conformist approach to CSR

Economic, ethical and legal responsibilities
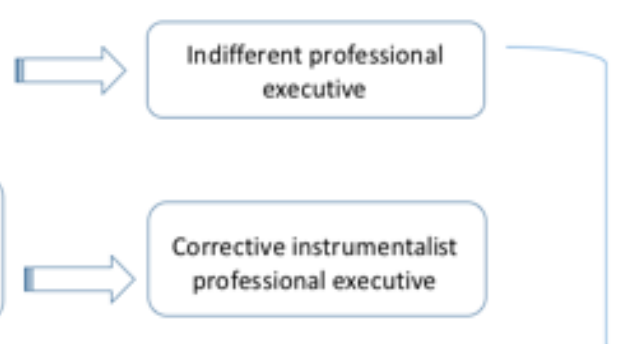

Professional -executives' agency

Compensation for the negative impact of the corporation on the society and

environment

Environmentalist agenda

Corrective instrumentalist professional executive
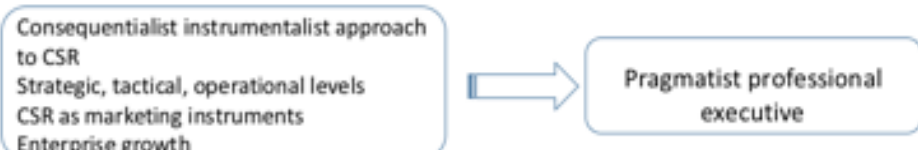

Enterprise growth

Holistic perspective of society and role of corporations

Stakeholder relationship management

Enterprises with an extended ownership

Value-based enlightened professional executive

Managerial capital and rationalized approach

Enterprise focus executive

Strategic and reflexive outlook 


\section{Figure 2. Typology of owners and professional executives vis-à-vis CSR approach}

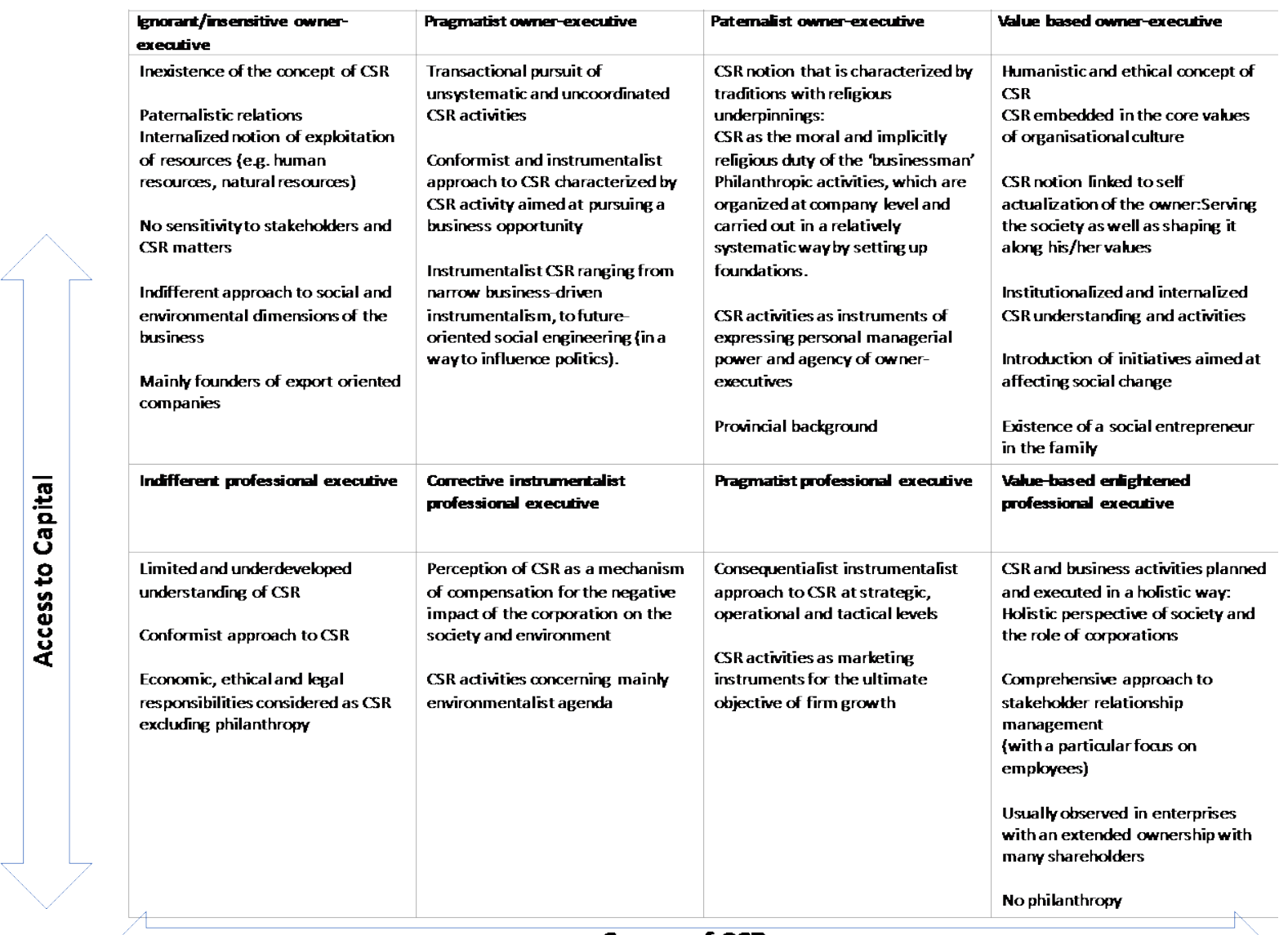




\section{Appendix1: Respondent characteristics}

\begin{tabular}{|c|c|c|c|c|c|c|}
\hline Interviewee & Position & $\begin{array}{l}\text { Birth } \\
\text { year }\end{array}$ & Education & Gender & Sector & Type of company \\
\hline Owner & Director & 1975 & Bachelor & M & $\begin{array}{l}\text { Manufacturing, } \\
\text { Energy }\end{array}$ & Group of companies \\
\hline Owner & Chairperson & 1958 & Secondary & M & $\begin{array}{l}\text { Manufacturing, } \\
\text { Finance, Services, } \\
\text { Logistics, Foreign } \\
\text { Trade }\end{array}$ & Group of companies \\
\hline Owner & Chairperson & 1955 & Primary sch & M & Food & Single company \\
\hline Owner & Chairperson & 1966 & Bachelor & M & $\begin{array}{l}\text { Manufacturing, } \\
\text { Tourism }\end{array}$ & Group of companies \\
\hline Owner & Chairperson & 1939 & Bachelor & M & Manufacturing & Single business \\
\hline Owner & Chairperson & 1945 & Master & M & $\begin{array}{l}\text { Finance, Retail, } \\
\text { Construction }\end{array}$ & Group of companies \\
\hline Owner & Chairperson & 1954 & Bachelor & M & Manufacturing & Group of companies \\
\hline Professional & CEO/director & 1945 & $\mathrm{PhD}$ & M & $\begin{array}{l}\text { Manufacturing, } \\
\text { Services, Airlines }\end{array}$ & Group of companies \\
\hline Owner & Chairperson & 1940 & Highschool & M & Food & Single business \\
\hline Owner & CEO/director & 1951 & Bachelor & $\mathrm{F}$ & $\begin{array}{l}\text { Manufacturing, } \\
\text { Tourism }\end{array}$ & Group of companies \\
\hline Owner & Chairperson & 1953 & Master & M & Manufacturing & Group of companies \\
\hline Owner & Director & 1954 & Bachelor & $\mathrm{F}$ & $\begin{array}{l}\text { Manufacturing, } \\
\text { Construction, } \\
\text { Logistics }\end{array}$ & Group of companies \\
\hline Owner & Director & 1966 & Bachelor & $\mathrm{F}$ & Manufacturing & Single business \\
\hline Professional & CEO/director & 1949 & $\mathrm{PhD}$ & M & Manufacturing & Group of companies \\
\hline Owner & Chairperson & 1941 & Highschool & M & Manufacturing & Single business \\
\hline Owner & Chairperson & 1963 & Bachelor & M & $\begin{array}{l}\text { Manufacturing, } \\
\text { Foreign Trade, } \\
\text { Agriculture }\end{array}$ & Group of companies \\
\hline Owner & Chairperson & 1942 & Bachelor & $\mathrm{M}$ & Textile & Single business \\
\hline Professional & CEO/director & 1967 & Bachelor & $\mathrm{M}$ & Steel & Single business \\
\hline
\end{tabular}




\begin{tabular}{|c|c|c|c|c|c|c|}
\hline Owner & Chairperson & 1948 & Secondary & $\mathrm{M}$ & $\begin{array}{l}\text { Manufacturing, } \\
\text { Energy, } \\
\text { Transportation }\end{array}$ & Group of companies \\
\hline Owner & Chairperson & 1966 & Master & M & $\begin{array}{l}\text { Manufacturing, } \\
\text { Finance, Energy, } \\
\text { Agriculture }\end{array}$ & Group of companies \\
\hline Owner & Chairperson & 1926 & Secondary & M & Food & Single business \\
\hline Owner & Chairperson & 1953 & Bachelor & $\mathrm{M}$ & $\begin{array}{l}\text { Manufacturing, } \\
\text { Tourism }\end{array}$ & Group of companies \\
\hline Owner & Chairperson & 1931 & Primary sch & $\mathrm{M}$ & $\begin{array}{l}\text { Manufacturing, } \\
\text { Tourism, Mining }\end{array}$ & Group of companies \\
\hline Owner & CEO/director & 1966 & Bachelor & M & Food & Single business \\
\hline Owner & Chairperson & 1955 & Master & $\mathrm{M}$ & $\begin{array}{l}\text { Manufacturing, } \\
\text { Construction, Tourism }\end{array}$ & Group of companies \\
\hline Owner & Chairperson & 1959 & Bachelor & $\mathrm{M}$ & $\begin{array}{l}\text { Energy, Tourism, } \\
\text { Media }\end{array}$ & Group of companies \\
\hline Owner & Chairperson & 1944 & Highschool & M & Textile & Single business \\
\hline Owner & Chairperson & 1959 & Bachelor & $\mathrm{M}$ & Packaging & Single business \\
\hline Owner & Chairperson & 1946 & Highschool & M & Chemicals & Single business \\
\hline Owner & Director & 1972 & Master & M & Food & Single business \\
\hline Owner & Chairperson & 1970 & Bachelor & $\mathrm{M}$ & $\begin{array}{l}\text { Manufacturing, } \\
\text { Services, Agriculture }\end{array}$ & Group of companies \\
\hline Professional & CEO/director & 1953 & Master & M & $\begin{array}{l}\text { Finance, } \\
\text { Manufacturing, } \\
\text { Construction, Tourism }\end{array}$ & Group of companies \\
\hline Professional & CEO & 1946 & Master & $\mathrm{M}$ & $\begin{array}{l}\text { Services, } \\
\text { Construction, } \\
\text { Manufacturing }\end{array}$ & Group of companies \\
\hline Owner & Chairperson & 1949 & Master & $\mathrm{M}$ & $\begin{array}{l}\text { Services, } \\
\text { Manufacturing, } \\
\text { Construction, Finance }\end{array}$ & Group of companies \\
\hline Owner & Chairperson & 1955 & Master & M & Manufacturing & Group of companies \\
\hline Owner & Chairperson & 1966 & Bachelor & M & Manufacturing & Group of companies \\
\hline
\end{tabular}




\begin{tabular}{|c|c|c|c|c|c|c|}
\hline Owner & Director & 1963 & Bachelor & M & $\begin{array}{l}\text { Services, } \\
\text { Construction, } \\
\text { Manufacturing, } \\
\text { Tourism, }\end{array}$ & Group of companies \\
\hline Owner & Chairperson & 1945 & Highschool & M & $\begin{array}{l}\text { Logistics, } \\
\text { Manufacturing, } \\
\text { Agriculture, Tourism }\end{array}$ & Group of companies \\
\hline Owner & Chairperson & 1957 & Master & M & Chemicals & Single business \\
\hline Professional & CEO/director & 1943 & Master & M & $\begin{array}{l}\text { Energy, } \\
\text { Manufacturing, } \\
\text { Construction }\end{array}$ & Group of companies \\
\hline Professional & $\begin{array}{l}\text { Director-Vice } \\
\text { Chairperson }\end{array}$ & 1949 & Bachelor & $\mathrm{F}$ & Agriculture, Services & Group of companies \\
\hline Professional & CEO/director & 1957 & Bachelor & M & $\begin{array}{l}\text { Energy, } \\
\text { Manufacturing }\end{array}$ & Group of companies \\
\hline Owner & Chairperson & 1933 & Primary sch & $\mathrm{M}$ & $\begin{array}{l}\text { Mining, } \\
\text { Manufacturing, } \\
\text { Animal Breeding, } \\
\text { Construction }\end{array}$ & Group of companies \\
\hline Professional & Chairperson & 1939 & Bachelor & M & Chemicals & Single business \\
\hline Owner & Chairperson & 1946 & Secondary & M & Manufacturing & Group of companies \\
\hline Owner & Chairperson & 1960 & Prebachelor & M & Manufacturing & Group of companies \\
\hline Owner & Chairperson & 1950 & $\mathrm{PhD}$ & M & Manufacturing & Group of companies \\
\hline Owner & Chairperson & 1941 & Highschool & M & Textile & Single business \\
\hline Owner & CEO/director & 1949 & Master & M & $\begin{array}{l}\text { Manufacturing, } \\
\text { Tourism, Services, } \\
\text { Energy }\end{array}$ & Group of companies \\
\hline Owner & Chairperson & 1966 & Bachelor & M & $\begin{array}{l}\text { Manufacturing, } \\
\text { Services }\end{array}$ & Group of companies \\
\hline Professional & CEO/director & 1955 & Master & M & Automotive & Single business \\
\hline Owner & Chairperson & 1950 & Bachelor & M & Manufacturing & Group of companies \\
\hline Professional & Chairperson & 1945 & Bachelor & M & Manufacturing & Group of companies \\
\hline Professional & Chairperson & 1950 & Bachelor & M & Manufacturing & Group of companies \\
\hline Owner & Director & 1956 & Bachelor & M & $\begin{array}{l}\text { Manufacturing, } \\
\text { Animal Breeding }\end{array}$ & Group of companies \\
\hline Owner & Chairperson & 1961 & Bachelor & $\mathrm{F}$ & Manufacturing & Group of companies \\
\hline
\end{tabular}




\begin{tabular}{|c|c|c|c|c|c|c|}
\hline Owner & CEO/director & 1957 & Bachelor & M & Manufacturing & Single Business \\
\hline Owner & Chairperson & 1936 & Master & $\mathrm{M}$ & Construction, Mining & Group of companies \\
\hline Owner & Chairperson & 1965 & Master & $\mathrm{F}$ & $\begin{array}{l}\text { Energy, } \\
\text { Manufacturing, } \\
\text { Media, Finance }\end{array}$ & Group of companies \\
\hline Owner & Chairperson & 1948 & Master & M & $\begin{array}{l}\text { Energy, Services, } \\
\text { Telecommunication }\end{array}$ & Group of companies \\
\hline Owner & CEO/director & 1954 & Bachelor & M & Food & Single business \\
\hline
\end{tabular}

